Sciences

Vol. 07, No. 01, pp. 119-134, March 2014

\title{
COMPARING DESIGN QUALITY FOR SCHOOL BUILDINGS IN IRAQ \\ (DIRECTORATE GENERAL OF EDUCATION IN DIYALA CASE STUDY)
}

\author{
Wadhah Amer Hatem \\ Baquba Technical Institute/ Diyala/ Iraq \\ E-mail: Wadhah7@yahoo.com \\ (Received: 28/4/2013; Accepted: 30/7/2013)
}

\begin{abstract}
Design quality has many definitions according to the field being considered. In the construction industry, the term design quality can be defined as the ideal design that satisfies all the project parties in terms of cost, time, and material specification and so on. Design quality measurement is considered from the point of view of complex tasks in the construction industry because of the differences in the stakeholders' opinions regarding each item in the design such as whether is it safe, comfortable, attractive in style. etc. This paper compares the design quality of two types of school buildings in Iraq and uses the design quality indicator toolkit DQI which was developed by Gann et al. [1]. The results show that the design quality for the closed school building was superior to that of the U-shape building in many aspects.
\end{abstract}

Keywords: Design quality indicator, Design schools, Design quality measurement.

\section{1- INTRODUCTION}

Design quality measurement is considered from the complex issues in the construction industry because each project consists of many activities and numerous items therefore to obtain the same level of quality in each item by different projects' parties such as designers, users, project owners is very difficult and may be impossible. Different users of a building will have varying views on the meaning of quality; the user will measure quality in subjective terms by considering the comfort levels of lighting, cooling, heating, the minimum waiting time for lifts, and so on. It is also important to point out, that the user is concerned which the manner in which the building performs the function for which it is required. However, the design quality is difficult to compute since it consists of objective and subjective components which rely on subjective preferences and opinions [2]. 
Successful design comes about where the continuous tracing of customer needs concerning service quality and a suitable cost are essential issues for any project [3]. During the design phase, it is important to include appropriate and accurate construction knowledge in order to avoid prospective problems in the final design [4]. The weakness and deficiency of the construction information throughout the design process may therefore hinder the project execution with the project exceeding the budget and schedule [5]. The quality of the design should be at a high level when there is shared knowledge which is understood by everybody working on the design. This characteristic also depends on the quality of the information in addition to whether or not it is successfully or punctually passed around the design team at different stages in the design phase [6].

Some researchers have focused on deviations in the design and construction stages, showing that most deviations in the project budget and time table are associated with poor design. Burait et al. [7] asserted that $78 \%$ of the total number of deviations is related to design deviations and represents $79 \%$ of the total number of deviations in project budgets. Andi \& Minato [8] also claimed that contract amendments are most affected by three major factors: design deficiencies, unidentified site conditions and requested changes by the client. They additionally revealed that $56 \%$ of all contract adjustments are requested to correct design weakness.

Design quality is therefore affected by numerous factors which reduce the designers' abilities and ultimately lessen the quality of the design. Here, Love et al. [9] asserted that deficiencies in design and weakness in information transformation between parties at the design phase can lead to a large proportion of reworking and thereby result in increasing costs. In addition to that from the financial aspect, the reduction in the design fees for the designers' team and the limited time for the design process can clearly lead to a decrease in the design quality. Egan [10] claimed that some of these factors related to construction industry issues, such as the nature of the design, the project budget and the standard requirements of the product. Moreover, there are further problems relating to the relationships of particular parties. Baigent [11] revealed that the expertise level of the designers is a greater influential factor affecting design quality, and a lack of experience on the part of the designer's staff, poor knowledge about the full design details as well as a dearth of staff training as regards new technologies in design will also affect design quality.

\section{RELATED WORKS}

A few methods have been used to measure design quality, such as those surveyed by Castro-Lacouture \& Ramkrishnan [2]. These methods are derived from initiatives to develop 
post occupancy assessment tools and quality indicators, such as the Bishop Method which depends on evaluation by the users and evaluators; these answer a series of questions to assess three factors in construction building, namely those of function, form and economy [12]. The users and evaluators assign a score from 1 to 10 for the three factors and the design quality of the building is determined by calculating the area of the triangle formed through plotting the score of the three factors. The Harmony Method, which was developed by Smith [13], is characterised by taking on a more subjective and intuitive approach. This method consists of a program to organize subjective assessments in order to reach a value judgement, which then allows a comparison with the observations of others. This method consists of five parts: three parts are related to single building assessments and the other two relate to urban planning. The final sheet contains the algebraic totals of the relevant parts.

Gifford et al. [14] produced the Modified Lens Model which provides a framework to represent the ways in which different groups respond to particular features of the built environment. This method combines these reactions into emotional impressions which it then translates in to an overall aesthetic assessment of the building. The aesthetic preferences of engineers and architects are then compared with those of a lay-person to obtain a valuable way of establishing which definite features and emotional responses encourage differences in the assessments made by the two groups. Another method is the DTLR [15] developed Housing Quality Indicator. This method assesses the house projects quality, and focuses on the relationship between the projects and the local environment. Leaman \& Bordass [16], for their part, used the PROBE Method (the post-occupancy review of building and engineering). This is based on the post-occupancy assessment tool which provides design and build teams, commissioning clients and building' occupiers with valuable snapshots of users' perceptions as well as any evaluation of the technical and energy performance of a building.

Gann et al. [1] developed the Design Quality Indicator (DQI) this being one of the most widely used methods to quantify the design quality of the building. The development in this toolkit was started by the Construction Industry Council in 1999 [17] and was launched online in the UK construction industry in 2003. The indicator DQI is used as a tool to assess design quality in a construction project with the purpose of summarising and organising stakeholders' evaluations of design quality. DQI is achieved through the completion of a questionnaire by all of the project parties for every item in the project; the DQI should be completed by 5 to 25 respondents, although there is no limit placed on this number [18]. Here, the analysis of the questionnaire results gives an indication of the design quality, from concept to construction as well as to occupation and maintenance. The DQI is a short, simple and a non-technical set of statements which collects the views of all those involved in the construction by looking at the functionality, build quality and impact of a building. 
- Functionality is related to the way in which a building is designed to be useful, this being divided into the categories of use, access and space.

- Build quality relates to the performance of a building's fabric and has three sections: performance, engineering and construction.

- The impact of a building refers to the building's ability to create a sense of place, and to have a positive effect on the local community and environment. This section subdivides into character and innovation, form and material, internal environment, urban and social integration [1].

Through a graphical illustration of the DQI results, the users can see the impact of their weighting as well as the scoring of the different sections by using a spider-diagram approach [1] (see Figure 1). There are two versions of the DQI: the generic tool, which can be applied to any building project, and the DQI for schools building, which was used in this research. The latter is a version of a tool that is more applicable to the needs of a school and can be used on all types of school projects. This tool can also help stakeholders, such as teachers, parents and students [19].

There is very little research related to design quality in the sector of school buildings in Iraq. Omran [20] has indicated that no total quality management system is applied to school buildings in Iraq especially as regards design; this information was obtained by conducting interviews and questionnaires with engineers working in the field of school buildings.

Omran [20] therefore created a program to simulate the application of a total quality management system with different approaches and benefits. This entailed adopting the application of the program of contracting companies, and school building directorates, but the program was limited in certain aspects of the construction, such as the unit price contract, the schedule rates contract and the methods of the projects implementations. In all previous studies related to design quality in school buildings in Iraq no research had dealt with this point. The research here however used DQI to measure this particular quality for these types of buildings and was a good indicator for evaluating the quality of the design.

\section{METHODOLOGY}

The purpose of the research described in this paper is to compare the design quality in Iraqi school buildings. Two models used in Iraq are studied here: the first one is of the old style which is still used today the U-shape school (see Figure 2). The second style, on other hand, represents the more modern style, this being a closed school (see Figure 3). The methodology used in this research was that of a questionnaire and was designed to measure 
the design quality for each type of school building. The main aspects the design quality for these types of constructions building were addressed in the questionnaire, namely the three categories of DQI (i.e. the functionality, build quality and impact of the building). Some of the items of DQI in this paper were rewritten to make them more understandable and clearer for the people participating in the research. This questionnaire therefore consists of numerous items (as shown in the Appendix 1). It included:-

A-Personal information for the people participating in the questionnaire, such as age, educational level, job and so on.

B-Twenty questionnaire items, including those in DQI and certain other items listed below:(1)-school building access;(2)-spaces for the students both inside and outside the classrooms;(3)- the lighting and ventilation of the buildings;(4)-the impact of the buildings on the surrounding buildings;(5)-the materials used to build the schools and their suitability for the Iraqi environment;(6)-the school environment and gardens;(7)-the security system used to protect the students;(8)-play grounds and stadiums;(9)-the external fence;(10)-students restaurants and food shops;(11)-electrical services for the schools;(12)-the W.C services.

The questionnaire was applied to each type of building, these being used for both primary and secondary schools. This research was conducted under the Directorate General of Education in the Diyala-department of school buildings and some of the schools belonging to this directorate. Altogether 50 people participated, these being designers, engineers, site engineers, schools heads, teachers, contractors, material suppliers, students and services workers. All those who participated in the questionnaire had experience in both types of the buildings, their years of experience ranging between (2 and 25) years. Table (1) sets out the details of those who took part.

Two questionnaire forms were distributed, one for the U-shape school building and the other for the closed school building this constituted 50 question for the U-shape structure and 50 for the closed school building. Each questionnaire was analyzed separately, every item in the questionnaire having five possible ratings, with 5 denoting excellent, 4 very good, 3 good, 2 bad and 1 very bad; these ratings were taken from Likert questionnaire [21].

To make the research results more valid, the t-test statistical analysis was used. This method determines the differences between the means of two independent samples and establishes whether the differences may be considered as statistically significant or not [22]. The t-test is widely used because it is simple, easy to use and can be applied to a small sample size [23].

\section{RESULTS AND DISCUSSION}


This work is mainly focussed on determining which type of school (i.e. the U-shape or closed building) has a higher design quality. A considerable degree of thought and effort went into determining this indicator with a full analysis for the questionnaire to enable the main points in the construction design to be considered. Figure (4) shows a spider diagram visualization to compare the design quality for both types of school building; the blue line represents the U-shape school while the red line indicates the closed school. Here, the results show the average of the 50 questionnaires for each type of building (i.e. each element from the DQI in this research represents an average for the 50 questionnaires responses).

It is clear that the design quality indicator for closed schools was higher than for Ushape schools in most of the DQI elements, and was equal in three of the elements, these representing the impact of the building. However, both lines followed very similar trends. Generally, with both types of school, the design quality indicator did not obtain the full number of design quality indicators this being 5 for each element.

For functionality, the design quality indicator for the closed school was $33 \%$ higher than for the U-shape school. The average of DQI in the functionality concept was 3.45 for closed schools, while it was 2.6 for U-shape school. This is a significant statistical difference between the two averages because the t-value of the "two-tailed test', from the analysis of the results was 3.54 , this being greater than the corresponding t-critical value of 2.77 , with a degree of freedom of $d f=4$ and a probability of error $<5 \%$. This means the closed building was better than the U-shape school as regards this concept. This could be attributed to a number of possibilities. For example, with the modern building the access is safer and more regard is given to the security system than with the old style. Moreover, the design is more suitable for the users than the U-shape school, this meeting the need for the required spaces for each student in the school.

As regards the second main aspect for the DQI indicator, namely, the impact of the building, it is clear that for both types of building the design quality indicator was nearly the same, with the differences being relatively small. The average of this indicator for impact was 3.03 for the closed school and 2.95 for the U-shape school. Hence, there was no significant statistical difference between the two averages since the t-value of the 'two-tailed test' from the results analysis was 0.109 ; this is less than the corresponding $\mathrm{t}$-critical value of 2.45 with a degree of freedom of $d f=6$, and a probability of error $>5 \%$. Therefore, there is no difference in the design quality for this element. This result may have come about for a variety of reasons, such as identical materials being used for the two types and there being an absence of attractive points in comparison with the surrounding buildings or the building being too normal and not causing people outside to think about these types of buildings (i.e. there not being any innovative ideas in the current school designs). 
As regards the third part of the DQI diagram, namely, the build quality, it is obvious the design quality indicator for this aspect was slightly higher than other the two aspects. However, the DQI for the closed school was higher than that of the U-shape school by $45 \%$. Here, the average of DQI in the design quality for the closed schools was 4.35 while for the U-shape school it was 3.0. This can be considered a significant statistical difference between the two averages because the t-value as calculated from the results analysis of 'two-tailed test' was 14.06. This is greater than the corresponding t-critical value of 2.77 with a degree of freedom $d f=4$, in addition to the probability of error $<5 \%$. This result indicates that the build quality for the closed building was better than with the U-shape school, and generally came about because in modern building the construction, performance and engineering system were improved upon and used advance methods in building construction.

Overall, and as seen in Figure 4, the general DQI which was combined with all three elements (i.e. functionality, the build quality and the impact of the building) can be calculated by taking an average for all the element scores in the diagram (i.e. the10 elements). The general DQI for the closed building (where the average=6.22) is higher than the U-shape school (average $=2.86$ ) by 24\%. This shows a significant statistical difference between the two averages because the t-value of the 'two-tailed test' from the analysis of the results was 7.42, which was greater than the corresponding t-critical value of 2.10 with a degree of freedom $d f=18$ and a probability of error $<5 \%$.

In order to provide more details about the three categories of the DQI indicator, it is useful to study each element separately and to analyze all the questionnaire categories (i.e. functionality, the impact of the building and the build quality). Figure 5 illustrates the relationship between the quality degree, this being represented where the gradations were excellent, very good, good, bad and very bad. With the number of responses for the functionality aspect, it is clear that the rating of 'good' represents the main group in the figure for both types of schools, while the quality degree denoted by (good, very good and excellent) for the closed school was still higher in comparing with the U-shape school. Inversely, where bad and very bad are indicated, it is clear that the number of responses showing the U-shape school was worse than the closed school. Those for the latter were higher, indicating that the closed building had a better design quality than the U-shape school.

Similarly, in terms of the build quality, Figure 6 demonstrates the relationship between the degrees of quality and their responses. It is clear that, the distribution of the data in Figure 6 is the same as in Figure 5 and the grade of good is clearly higher than the other categories from the data in the figure. In addition, on the positive side it is obvious that the number of those choosing a positive description indicated that the design quality for the closed school was higher than for the U-shape school while on the negative side, the 
participants also indicated that the closed school was better than the U-shape school. This supports the results above, demonstrating that the design quality indicator for the closed school was higher.

As regards the impact of the building, Figure 7 makes it clear that the data has the same distribution as in Figures 5 and 6. However, in terms of the positive aspects including excellent, very good and good, the quality of the building was still higher for closed schools. This an also been seen with the negative sides of the figure, which show that the closed school was preferred to the U-shape school. It can therefore be said that the above results prove that the design quality for the closed school is higher than for the U-shape school).

\section{CONCLUSION AND RECOMMENDATIONS}

In this paper the design quality indicator for the two types of school building (U-shape and closed) were determined through an analysis of DQI questionnaires. Significantly, neither type of school building, obtained a full mark in its design quality aspect. Overall, the design quality indicator for the closed school was higher than for the U-shape school by (24\%). As regards the main DQI elements in functionality, the design quality indicator for the closed school was (33\%) higher than the U-shape school, while for the build quality aspect, the design quality indicator for the closed school building was (45\%) higher than for the U-shape school. In terms of the impact of the building aspect, there were no differences between the two types of school buildings.

The grade of "good" was the highest grade for the two types of building which means that both schools were acceptable for an Iraqi environment. However, in an analysis of the questionnaires, it was clear that both types were poor within their gardens, stadiums, and play-grounds. In particular, in the U-shape schools, the security system was very weak and requires a rethink in the light of the Iraqi political situation to determine how to protect students with the best design.

\section{6-ACKNOWLEDGEMENTS}

I would like to express my thanks and gratitude to everyone who participated in this research and who enabled me to benefit from their experience; they all made it possible for me to present my research. In particular, I am grateful to all the engineers and staff at the Directorate General of Education in the Diyala-department of school buildings and to all the teachers, head teachers and students for their tremendous assistance: they deserve considerable recognition and without their help, this work would not have been possible. 


\section{REFERENCES}

1. D. M. Gann, A. G. Salter \& J. K. Whyte, Design quality indicator as a tool for thinking. Building Research and Information, 2003, Vol. 31(5), pp.318-333.

2. D. Castro-Lacouture \& K. Ramkrishnan, Fuzzy logic method for measuring building quality. Journal of Quality, 2008, Vol. 15(2), pp.117-129.

3. L. Wen-Baw, The exploration of customer satisfaction model from comprehensive perspective. Expert System with Application, 2007, Vol. 33(1), pp.110-121.

4. B. G. McCullouch, A decision tool for incorporating construction knowledge during design. In Langford, D. A. \& Retik, A. (ed). The organisation and management of construction: Shaping theory and practice, London: E \&FN Spon, 1996, Vol. 2, pp. 509-518.

5. B. Trigunarsyah, A review of current practice in constructability improvement case studies on construction projects in Indonesia. Construction Management \& Economics, 2004, Vol. 22(6), pp. 567-580.

6. M. H. Pulaski \& M. J. Horman, Organising constructability knowledge for design. Journal of Construction Engineering \& Management, 2005, Vol. 131(8), pp.911-919.

7. J. L. Burait, J. J. Farrington \& W.B. Bedbetter, Causes of quality deviations in design and construction. Journal of Construction Engineering and Management, ASCE, 1992, Vol. 118(1), pp. 34-49.

8. S. Andi \& T. Minato, Design documents quality in the japans construction industry Factors influencing and impact on construction process. International Journal of Project Management, 2003, Vol. 21 (7), pp.537-546.

9. P. E. D. Love, P. Mandel \& H. Li, A systematic approach to modelling the causes and effects of rework in construction. In: Proceeding of the $1^{\text {st }}$ International Conference on Construction Industry Developments: Building the Future Together Singapore, 4-8 July, 1997, Vol. 2, pp. 347-355.

10. J. Egan, Rethinking construction. Department of the environment, transport and the regions, London. Emmitt, S., architectural management-an evolving field, Engineering. Construction and Architectural Management, 1998, Vol. 6(2), pp. 188196.

11. A. Baigent, Engineering, documentation and litigation, AISC-IEAust Special Issue Steel Construction, 2000, Vol. 34(4).

12. J. Bishop, The appraisal of building: A case study and critique of approaches. Bristol: University of Bristol Press. UK, 1978.

13. P. Smith, Architecture and the principle of harmony. London: RIBA, 1987. 
14. R. Gifford, D. Hine, W. Muller-Clemm, D. J. Reynodlda \& K. Shaw, Decoding modern architecture: A lens model approach for understanding the aesthetic differences of architects and laypersons. Environment and Behaviour, 2000, Vol. 32, pp.163-187.

15. DTLR, Housing Quality Indicators, DTLR, London, 2000.

16. A. Leaman, \& B. Bordass, Assessing building performance in use: the probe occupant surveys and their implications. Building Research and Information, 2001, Vol.29, pp. 129-143.

17. N. Spencer \& G. Winch, How building add value for client. Thomas Telford, London, 2002.

18. P. Rogers, CIC design quality indicator online, 2012, Available at: http://www.dqi.org.uk/dqi/Common/DQIOnline.pdf. [Accessed January 2013].

19. R. A. Farooqui \& S. M. Ahmed, Designing for quality: An empirical study of design quality indicator (DQI) tool. In: Proceeding of $7^{\text {th }}$ LACCEI Latin American Caribbean for Engineering and Technology. San Cristobal, Venezuela, 2-5 June, 2009.

20. M. S. Omran, Establishing total quality management applications system for school building projects in Iraq. Journal of Engineering Technology, 2010, Vol.28 (14).

21. R. Likert, A technique for the measurement of attitudes. Archives of Psychology, 1932, Vol. 140(1), pp. 44-53.

22. F. Pyrczak, Success at statistics: A worktest with humor. $2^{\text {nd }}$ ed. Los Angeles: Pyrczak Publishing, 2002.

23. W. G. Cochran. \& M. C. Gertrude, Experimental Designs. $2^{\text {nd }}$ ed. New York: John Wiley \& Sons, 1992.

\section{Questionnaire}

This questionnaire was used to determine the design quality indicator of the school buildings.

\section{A-Personal information:}

1. Full name:

2. Which group you belong to:

Designer $\square$ Site engineer $\square$ Contractor $\square$ Teacher $\square$ Student $\square$ Other $\square$

3. Work experience:

Less than 5 years $\square$ 5-15 years $\square \quad$ 16-25 years $\square$ more than 25 years

No experience

4. Educational level:

Diploma $\square$ Bachelor $\square$ Master $\square \operatorname{PhD} \square$ Others $\square$ 


\section{B-Questionnaire items}

Tick one of the following options with 5 as excellent, 4 very good, 3 good, 2 bad and 1 very bad for the following questions.

\section{Functionality}

1-What is your opinion of the external building access location?
Excellent $5 \square$
$4 \square 3$
2
$1 \square$ Very bad

2-What do you think about the number of external forms of access?
Excellent 5
4
3
$2 \square$
$1 \square$ Very bad

3- What is your opinion concering the spaces for the classes?
Excellent 5

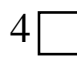
3
$2 \square$
$1 \square$ Very bad

4- How do you feel about the location of the internal doors for the classes?
Excellent $5 \square$
4
$3 \square$
$2 \square$
$1 \square$ Very bad

5- How easy is the building to operate?

Excellent $5 \square \quad 4 \square \quad 3 \square \quad 2 \square \quad 1 \square \quad$ Very bad

\section{Build quality}

6- What do you think about the lighting and ventilation inside the classes?
Excellent 5
4
$3 \square$
$2 \square$
$1 \square$ Very bad

7- How do you view the location of the windows for the classes?
Excellent 5
4
$3 \square \quad 2 \square$
$1 \square$ Very bad

8-What do you think about the number of windows for each class?
Excellent $5 \square$
$4 \square$
3
2
$1 \square$ Very bad

9-How good are the electrical functions of the building?.
Excellent $5 \square$
$4 \square$
$3 \square \quad 2$
$1 \square$ Very bad

10- What do you think about the security system?

Excellent $5 \square 4 \quad \square \quad 3 \quad \square 2 \quad \square \quad \square \quad \square 1$ Very bad

11-What do you think of the location of the W.Cs?
Excellent 5

$4 \square$
3
$2 \square$
$1 \square$ Very bad

12- What is your opinion about the external wall of the school (the fence)?
Excellent 5

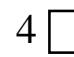
3
$2 \square$
$1 \square$ Very bad

13- What do you think about the location of the food shop?

Excellent $5 \square 4 \quad \square \quad 3 \quad \square 2 \quad \square \quad \square 1$ Very bad

14- How do you find the internal media?

Excellent $5 \square 4 \quad \square \quad 3 \quad \square 2 \quad \square \quad \square$ 1Very bad

15-How do you view the number of W.C units?

Excellent $5 \square \quad 4 \square \quad 3 \square \quad 2 \square \quad 1 \square \quad 1 \square$ Very bad




\section{Impact of the building}

16-What is your view on the school's location according to the surrounding buildings?
Excellent 5

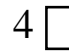
3
$2 \square$
$1 \square$ Very bad

17- What do you think about the building materials?
Excellent 5

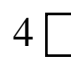
3
2
$1 \square$ Very bad

18- What do you think of the play-ground and gardens?
Excellent 5
4
3
$2 \square$
$1 \square$ Very bad

19- How do you view the building shape and if it makes you think?
Excellent $5 \square$
$4 \square$
3
$2 \square$
$1 \square$ Very bad

20-What do you think the isolation material for the building?
Excellent 5
4
3
$2 \square \quad 1$
Very bad

Table (1): Details of those participating in the questionnaire

\begin{tabular}{|c|c|c|c|c|c|c|c|}
\hline Job & $\begin{array}{c}\text { Designer } \\
\text { Engineer }\end{array}$ & $\begin{array}{c}\text { Site } \\
\text { Engineer }\end{array}$ & $\begin{array}{c}\text { Head } \\
\text { teachers } \\
\text { and } \\
\text { teachers }\end{array}$ & Contractors & $\begin{array}{c}\text { Materials } \\
\text { Suppliers }\end{array}$ & Students & $\begin{array}{c}\text { Service } \\
\text { workers }\end{array}$ \\
\hline Number & 4 & 20 & 10 & 4 & 2 & 8 & 2 \\
\hline $\begin{array}{c}\text { Educational } \\
\text { Level }\end{array}$ & $\begin{array}{c}3 \mathrm{BSc} \\
1 \mathrm{MSc}\end{array}$ & $\mathrm{BSc}$ & $10 \mathrm{BSc}$ & $\begin{array}{c}2 \mathrm{BSc} \\
\text { 2 Secondary }\end{array}$ & $\begin{array}{c}1 \mathrm{BSc} \\
1 \mathrm{Secondary}\end{array}$ & ---- & ---- \\
\hline
\end{tabular}

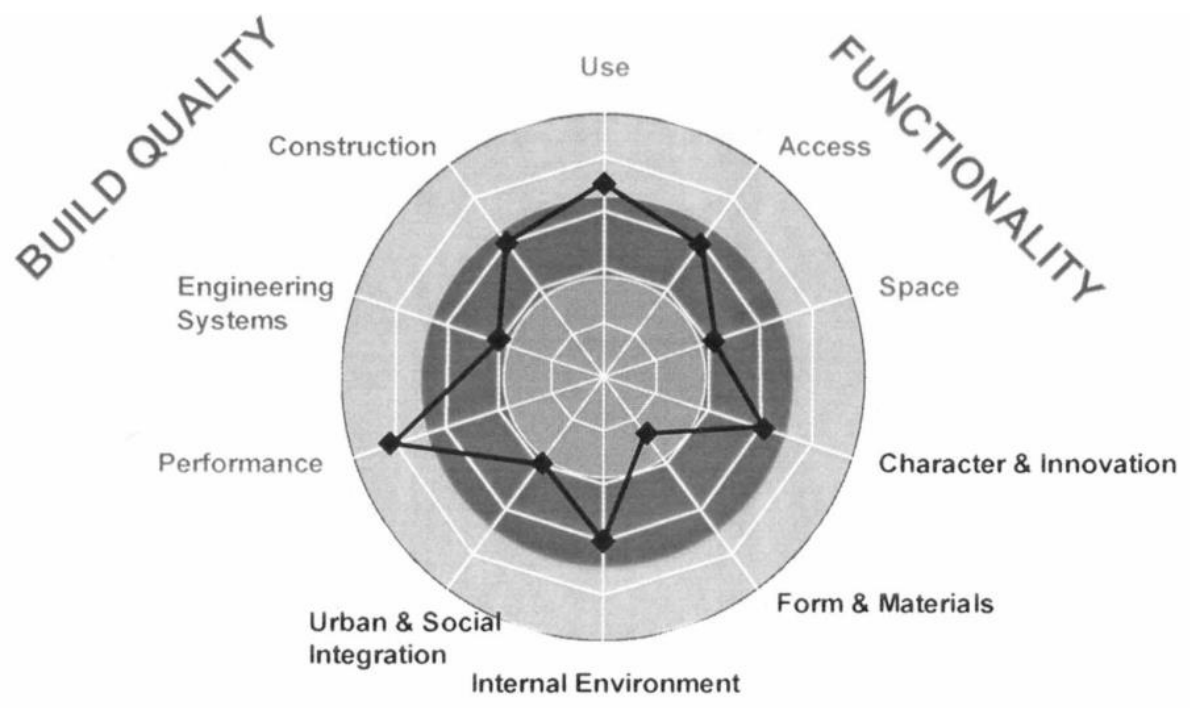

IMPACT

Figure (1): Spider diagram visualization [1]. 


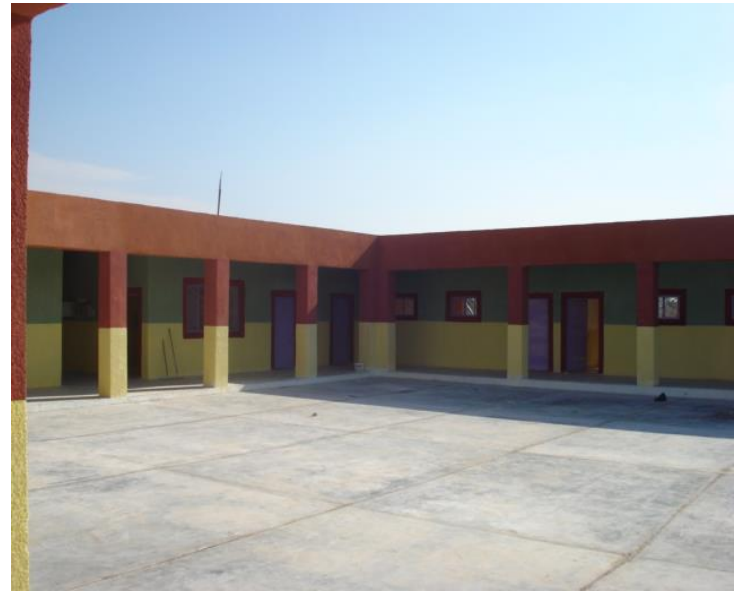

Figure (2): U-Shape School

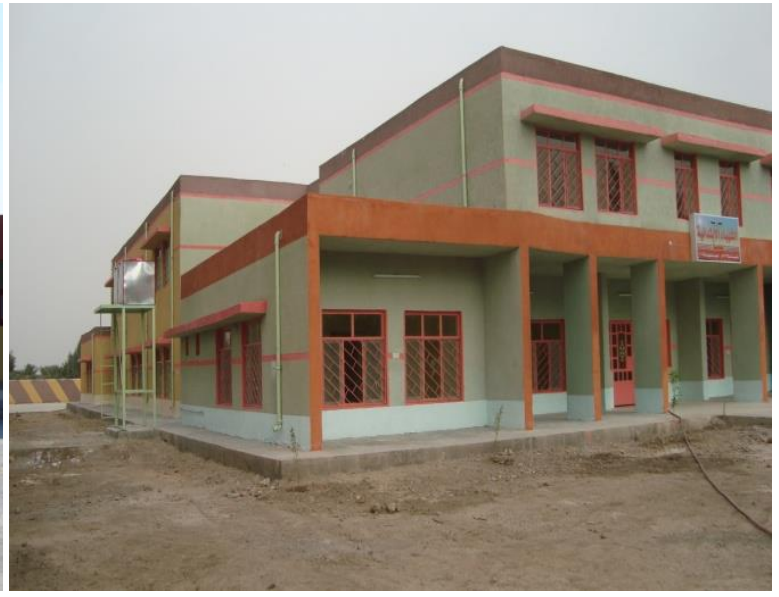

Figure (3): Closed school

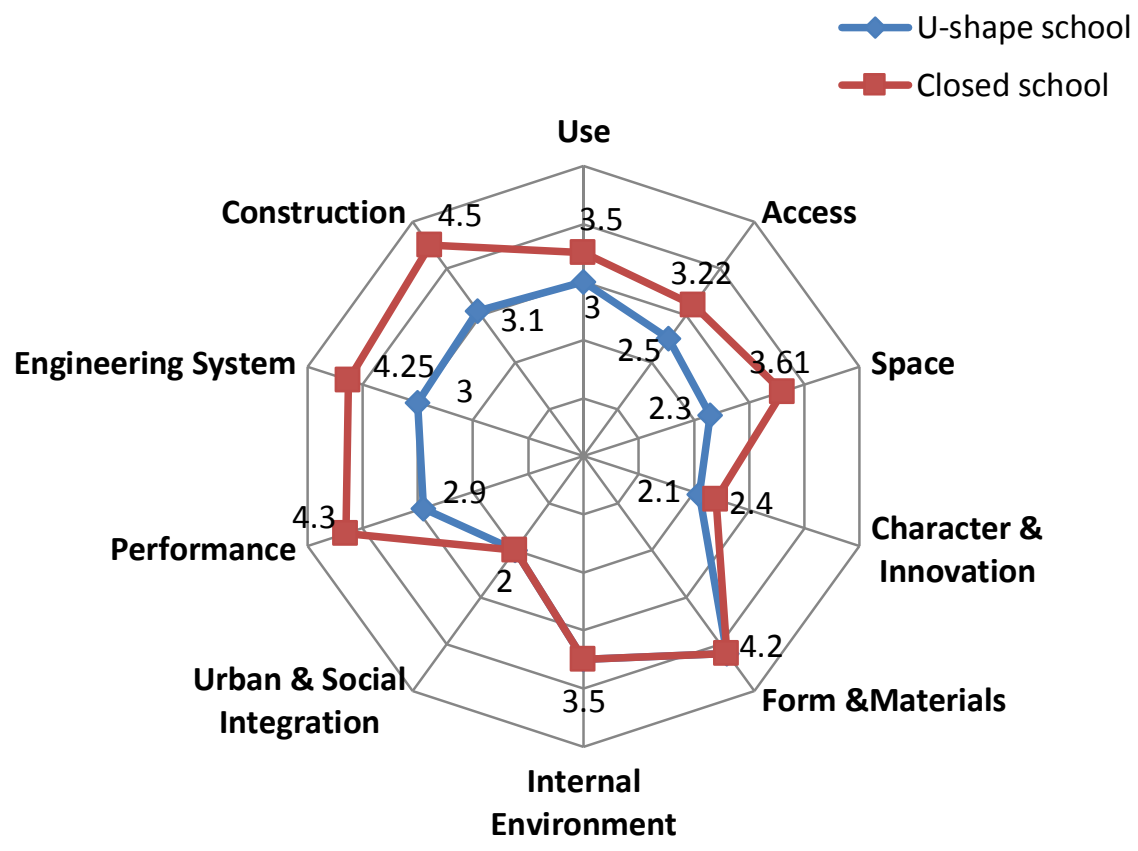

Figure (4): Design quality indicator for U-shape and closed schools. 


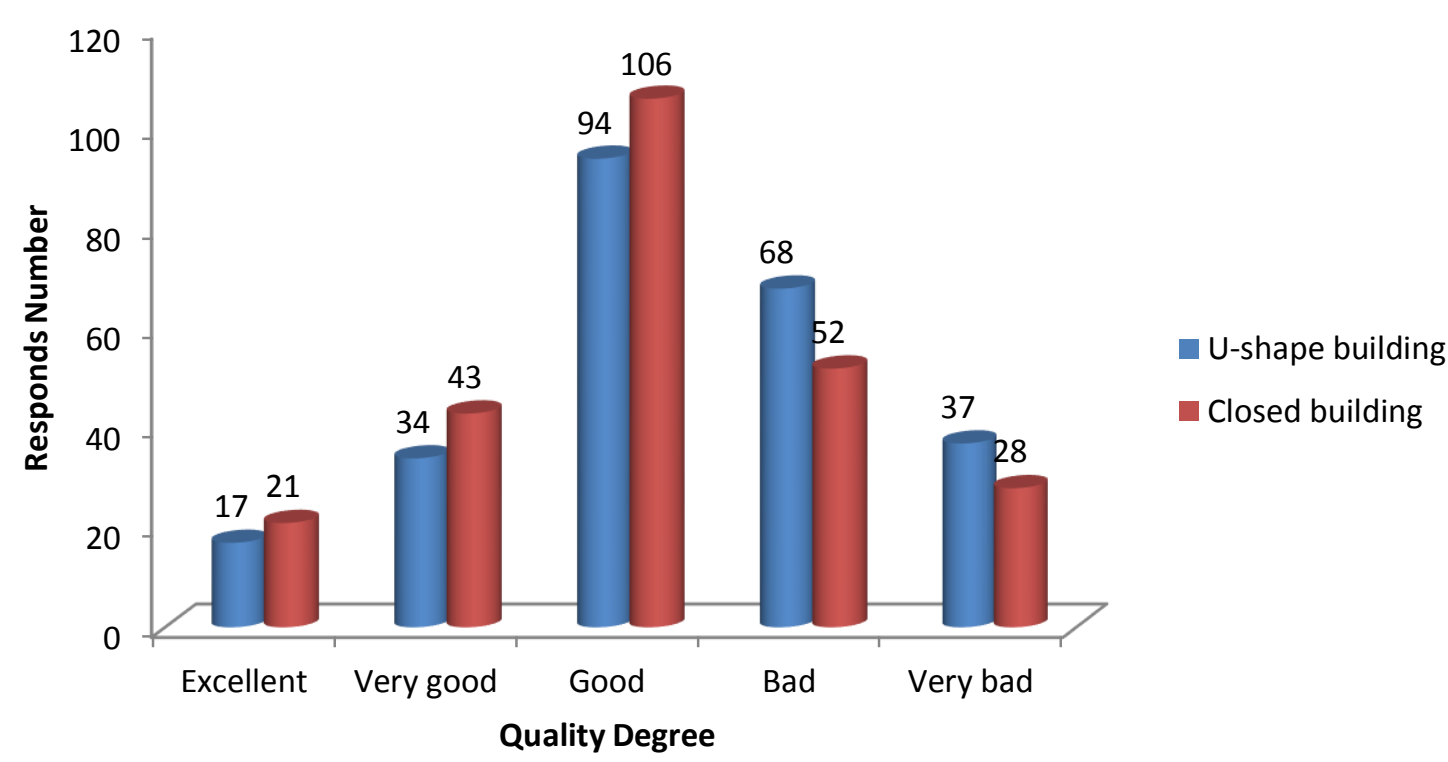

Figure (5): Functionality for both types of school buildings.

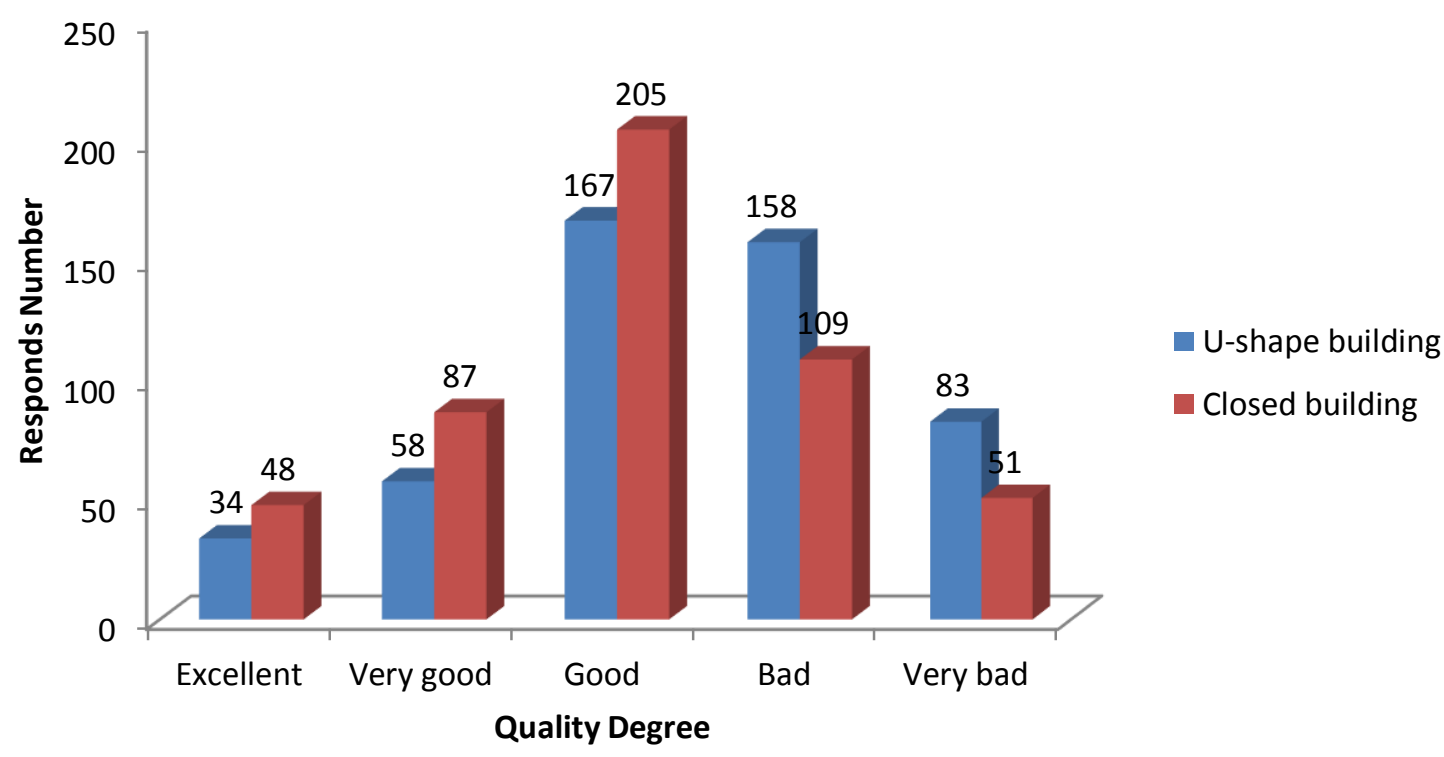

Figure (6): Build quality for both types of school buildings. 


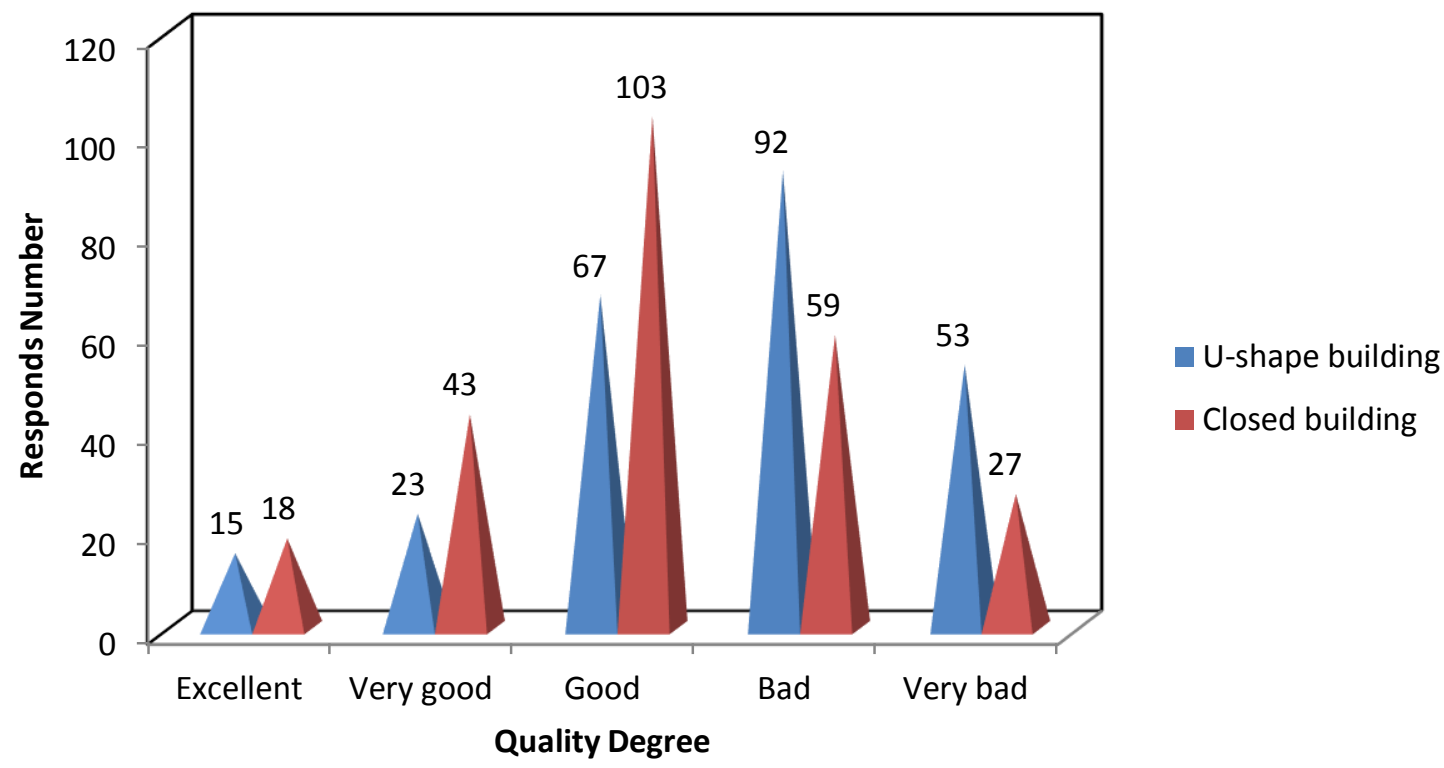

Figure (7): Impact of the building for both types of school buildings. 


\section{مقارنة جودة التصميم للأبنية المدرسية في العراق \\ (المديرية العامة لتربية ديالى)}

$$
\text { المعهد الثتني/ بعقوبة/ العراق حاتم }
$$

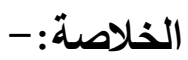

جودة التصميم لها عدة تعاريف تبعا الى نوع الحقل الذي يراد قياس جودة التصميم فيه. في مجال القطاع الانشائي يمكن

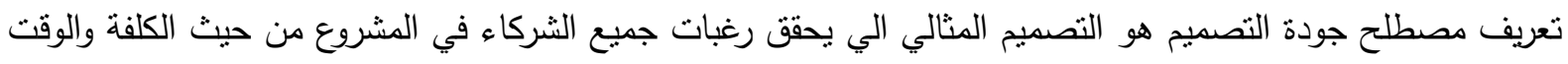
والمواصفات....الخ. قياس جودة التصميم يمكن اعتبارها من وجهة نظر المختصين من اصعب لصنب المهام في المشاريع الانثائية وذلك لاختلاف وجهات النظر اللشركاء في المشروع من حيث تعدد الاراء وحسب كل فقرة انثائية فيما اذا كانت مريحة,امينة رجذابة من حيث الثكل ....الخ.في هذا البحث تمت مقارنة جودة التصميم لنوعين من الابنية المدرسية المستخدمة في العراق وتم استخدام مؤشر جودة التصميم والذي طور من قبل (جان واخرون.2003 ). لقد بينت النتائج في هذا البحث ان جودة التصميم للابنية المغلقة كانت تتقوق على نظيرتها في مدارس الابنية المفتوحة في عدة جوانب. 